\title{
Prevalence of vitamin D deficiency in patients of pregnancy induced hypertension
}

\author{
Guljit Kaur, Sangeeta Pahwa, Ibadat Preet*
}

\begin{abstract}
Department of Obstetrics and Gynaecology, Shri Guru Ram Das Institute of Medical Sciences and Research, Amritsar, Punjab, India
\end{abstract}

Received: 29 November 2017

Revised: 03 June 2018

Accepted: 05 June 2018

\author{
*Correspondence: \\ Dr. Ibadat Preet, \\ E-mail: preetibadat@gmail.com
}

Copyright: (C) the author(s), publisher and licensee Medip Academy. This is an open-access article distributed under the terms of the Creative Commons Attribution Non-Commercial License, which permits unrestricted non-commercial use, distribution, and reproduction in any medium, provided the original work is properly cited.

\begin{abstract}
Background: The objectives of this study were to compare the serum Vitamin D levels in pregnant patients of pregnancy induced hypertension (PIH) and healthy normotensive patients and to study the prevalence of vitamin D deficiency in patients of PIH.

Methods: This study was conducted in Shri Guru Ram Das Institute of Medical Sciences and Research, Vallah, Amritsar in year 2015-2017. In total 100 cases were taken for the study and divided into two groups.

Results: Serum Vitamin D levels were quite low in women with pregnancy induced hypertension with a mean vitamin D levels of $13.006 \pm 6.24 \mathrm{ng} / \mathrm{ml}$ as compared to $23.239 \pm 10.601 \mathrm{ng} / \mathrm{ml}$ in healthy pregnant women. The prevalence of vitamin D deficiency in PIH group was very high i.e. $94 \%$ compared to $46 \%$ in normotensive group (Mean Vitamin D levels $<20 \mathrm{ng} / \mathrm{ml}$ ).

Conclusions: Vitamin D levels are deficient in patients of PIH and there is increased prevalence of vitamin D deficiency with PIH suggesting that vitamin D deficiency can be a risk factor for the development of PIH.
\end{abstract}

Keywords: PIH, Prevalence, Vitamin D

\section{INTRODUCTION}

Having a healthy pregnancy is one of the best ways to promote a healthy birth. Pregnancy nutrition is essential as nutrition of the fetus begins at conception. Micronutrients are only needed in very small quantities but are essential for normal physiological function, growth and development. Some of micronutrients deserve more attention as causes of poor pregnancy outcome, including other $\mathrm{B}$ vitamin deficiencies that result in homocysteinemia, antioxidants, vitamin D, and iodine.

Pregnancy induced hypertension (PIH) is defined as the hypertension that develops as a direct result of the gravid state. Every tenth pregnancy is affected by hypertension, one of the most common complications and leading causes of maternal death worldwide.

Apart from known risk factors such as stress, obesity, diabetes, and advanced age, low anti-oxidants, variations in trace metals and electrolyte disturbances have been linked with the pathogenesis of pre-eclampsia. ${ }^{1,2}$

Recent epidemiological studies have emphasized the role of vitamin D deficiency in the development of preeclampsia. $^{3}$

Vitamin D (Sunshine Vitamin) is a pro-hormone which plays significant role in bone metabolism via regulation of calcium and phosphate homeostasis. The prevalence of 
vitamin D deficiency is a public health concern. In pregnancy the same issue becomes critical as the impact is not only on the woman but extends to affect the fetus as well. Vitamin D deficiency has been historically defined and recently recommended as a $25(\mathrm{OH}) \mathrm{D}$ of less than $20 \mathrm{ng} / \mathrm{ml}$. Vitamin D insufficiency has been defined as a $25(\mathrm{OH}) \mathrm{D}$ of $21-29 \mathrm{ng} / \mathrm{ml}^{4-10}$

Pregnant and lactating women who take a prenatal vitamin and a calcium supplement with vitamin $\mathrm{D}$ remain at high risk for vitamin D deficiency. ${ }^{11-13}$

It is advisable to review vitamin D deficiency in mothers and their children so that strategies can be implemented to prevent vitamin $\mathrm{D}$ deficiency in pregnancy and lactation.

Present study also aimed to investigate the serum vitamin D levels in women with pregnancy induced hypertension and normal healthy pregnant women and to assess its role in the etiology of pregnancy induced hypertension.

It was a prospective study of the serum vitamin D3 levels in a group of women who presented to present antenatal clinic and labour and delivery suite after 20 weeks of gestation and were diagnosed with pregnancy induced hypertension. These levels were compared to the vitamin D3 levels in normotensive pregnant women.

\section{METHODS}

The present study included 50 patients of Pregnancy induced hypertension and 50 normotensive pregnancy patients presenting in Shri Guru Ram Das Medical Institute of Medical Sciences and Research, Sri Amritsar.

\section{Inclusion criteria}

Study group: Patients of Pregnancy Induced Hypertension with and without treatment- gestational hypertension, pre-eclampsia, eclampsia, HELLP syndrome.

Control group: Normotensive pregnant patients.

\section{Exclusion criteria}

Conditions known to cause Pregnancy Induced Hypertension i.e. multiple pregnancy, diabetes mellitus, chronic renal disease, chronic hypertension.

Table 1: Quantitative interpretation.

\begin{tabular}{ll} 
Level & Reference range \\
Deficient & $<20 \mathrm{ng} / \mathrm{ml}$ \\
\hline Insufficient & $20 \mathrm{ng} / \mathrm{ml}-30 \mathrm{ng} / \mathrm{ml}$ \\
\hline Sufficient & $30 \mathrm{ng} / \mathrm{ml}-100 \mathrm{ng} / \mathrm{ml}$ \\
\hline Intoxication & $>100 \mathrm{ng} / \mathrm{ml}$ \\
\hline
\end{tabular}

Assay procedure: The measurement of $25-\mathrm{OH}$ Vitamin D concentration in the serum or plasma was done by competitive chemiluminescence immunoassay (CIA).

\section{Statistical analysis}

Numerical variables were reported in terms of mean and standard deviation. An independent (unpaired) sample ttest was used to compare the difference of means for independent quantitative variables following normal distribution.

\section{RESULTS}

Mean age: In present study, the mean age of the study group was $27.74 \pm 4.539$ years as compared to $27.26 \pm 3.93$ years in case of controls. On statistical analysis, the pvalue was not significant. This indicates that the patients of both groups were age matched.

Mean Gestational age: The mean maternal gestational in present study was $34.063 \pm 3.58$ weeks in the study group as compared to $34.078 \pm 2.93$ weeks in the control group. On statistical analysis, the p-value was 0.3944 (not significant). This shows that the two groups of present study were similar in terms of gestational age at which serum vitamin D levels were measured.

Systolic and diastolic blood pressure in both groups: The mean SBP and DBP of patients of study group on admission was $159.24 \pm 23.50 \mathrm{mmHg}$ and $101.92 \pm 12.38$ $\mathrm{mmHg}$ and that of control group was $115.48 \pm 8.21 \mathrm{~mm}$ $\mathrm{Hg}$ and $76.70 \mathrm{mmHg}$. P-value was $<0.001$ proving that the mean values of SBP and DBP were significantly higher in the PIH subjects compared to the control ones.

Mean serum Vitamin D levels: In present study it was observed that serum Vitamin D levels were quite low in women with pregnancy induced hypertension with a mean vitamin $D$ levels of $13.006 \pm 6.24 \mathrm{ng} / \mathrm{ml}$ as compared to $23.239 \pm 10.601 \mathrm{ng} / \mathrm{ml}$ in healthy pregnant women. So, on comparing the vitamin D levels between the both groups, it was observed that the difference between two groups was highly significant with the $\mathrm{p}$ value of $<0.001$.

Table 2: Mean vitamin D levels in both groups.

\begin{tabular}{|ll|}
\hline Groups & Mean vitamin D levels \\
\hline PIH & 12.857 \\
\hline NT & 23.239 \\
\hline
\end{tabular}

Prevalence of vitamin D deficiency in Healthy Normotensive patients: In present study, only $28 \%$ of the candidates of healthy pregnant women had normal Vitamin D levels (i.e. mean Vitamin D >30ng/ml). So, the prevalence of Vitamin D deficiency was $46 \%$ and Vitamin D insufficiency was $26 \%$ pointing towards high prevalence of Vitamin D deficiency among pregnant women in India. 
Prevalence of vitamin D deficiency in patients of PIH: In present study group, only $4 \%$ patients had normal Vitamin D levels (Mean Vitamin D levels $>30 \mathrm{ng} / \mathrm{ml}$ ). So, the prevalence of vitamin D deficiency in PIH group was very high i.e. $94 \%$ compared to $46 \%$ in normotensive group (Mean Vitamin D levels <20 ng/ml).

In present study, severe Vitamin D deficiency (Mean Vitamin D levels $<10 \mathrm{ng} / \mathrm{ml}$ ) was seen in $44 \%$ in study group as compared to $10 \%$ in control group. This shows that there is high prevalence of Vitamin D deficiency in patients of PIH as compared to normotensive patients.

Table 3: Prevalence of vitamin D deficiency in both groups.

\begin{tabular}{|c|c|c|c|c|}
\hline $\begin{array}{l}\text { Serum vitamin } \\
\text { D (ng/ml) }\end{array}$ & PIH & Prevalence & NT & Prevalence \\
\hline Deficient $(<20)$ & 46 & 94 & 23 & 46 \\
\hline $\begin{array}{l}\text { Insufficient } \\
\text { (Between 20-30) }\end{array}$ & 2 & 4 & 13 & 26 \\
\hline Sufficient (>30) & 2 & 4 & 14 & 28 \\
\hline
\end{tabular}

\section{DISCUSSION}

In present study, the mean Vitamin D levels were significantly less in the study groups compared to the control group. This finding is consistent with the recent study of Sadin et al who found that serum 25(OH)D concentration was significantly lower in preeclamptic cases compared to controls $(10.09 \pm 6.66$ and $15.73 \pm 5.85$ $\mathrm{ng} / \mathrm{ml}$ respectively, $\mathrm{P}=0.002){ }^{14}$

This association was also accordant with findings of recent three systematic reviews and meta-analysis of observational studies conducted by Tabesh $\mathrm{M}$ et al, Aghajafari F et al and Wei SQ et al who found that maternal risk of preeclampsia has been associated with low maternal circulating level1 of $25(\mathrm{OH}) \mathrm{D} .^{1,15,16}$

In contrast to present study, in a study conducted by Umar $\mathrm{N}$ et al, it was observed that serum Vitamin $\mathrm{D}$ levels were quite low in both groups with a median vitamin D level of 14.04 (IQR $10.64 \mathrm{ng} / \mathrm{ml}$ ) in preeclamptic women; and in normotensive pregnant women. ${ }^{17}$

Median vitamin D level was found to be 13.8 (IQR 6.92 $\mathrm{ng} / \mathrm{ml}$ ). But on comparison of vitamin D levels between two groups, it was observed that the difference between groups was insignificant with p-value of 0.21 .

So, it was concluded that there is no association between serum Vitamin D levels and development of preeclampsia.

In present study, the prevalence of vitamin $\mathrm{D}$ deficiency was $94 \%$ in the study group as compared to $46 \%$ in the control group and that of severe Vitamin D deficiency was $44 \%$ in the study group and $10 \%$ in the control group.

Table 4: Studies comparing severe vitamin D deficiency in PIH group (mean S. vitamin D levels $<10 \mathrm{ng} / \mathrm{ml})$.

\begin{tabular}{|lll|}
\hline Studies & $\begin{array}{l}\text { Prevalence of } \\
\text { severe vitamin D } \\
\text { deficiency in } \\
\text { PIH group }\end{array}$ & $\begin{array}{l}\text { Prevalence of } \\
\text { severe vitamin D } \\
\text { deficiency in } \\
\text { control group }\end{array}$ \\
\hline $\begin{array}{l}\text { Present } \\
\text { study }\end{array}$ & 44 & 10 \\
\hline $\begin{array}{l}\text { Gupta } \\
\text { T et al }\end{array}$ & 90 & 62 \\
\hline $\begin{array}{l}\text { Mehmood } \\
\text { S et al }{ }^{19}\end{array}$ & 86.5 & 65.4 \\
\hline $\begin{array}{l}\text { Robinson } \\
\text { CJ et al }{ }^{20}\end{array}$ & 83.3 & 68 \\
\hline
\end{tabular}

In contrast to present study, in the recent study conducted by Goel P et al it was seen that all women (100\%) in group 1 had vitamin D deficiency as compared to $92 \%$ in group 2 but this was not statistically significant. $83.3 \%$ of women in hypertensive group had severe deficiency compared to $68 \%$ women in healthy pregnant women. ${ }^{21}$

This finding of present study was also in contrast with study conducted by Umar $\mathrm{N}$ et al in which it was found that severe vitamin D deficiency is present in $95 \%$ of preeclamptic and $62 \%$ normotensive pregnant women but the difference of vitamin $\mathrm{D}$ level between the two groups was not found significant. ${ }^{17}$

\section{CONCLUSION}

Hence from present study it was concluded that vitamin D levels are deficient in patients of PIH. However, association of vitamin D deficiency with the causation of PIH cannot be ascertained as the study was conducted after PIH has developed. Increased prevalence of vitamin D deficiency with PIH has been proved in present study. But there is a need for large scale studies and a bigger number needs to be evaluated for more detailed analysis.

Funding: No funding sources

Conflict of interest: None declared

Ethical approval: The study was approved by the Institutional Ethics Committee

\section{REFERENCES}

1. Kashyap MK, Saxena SV, Khullar M, Sawhney H, Vasishta K. Role of anion gap and different electrolytes in hypertension during pregnancy (preeclampsia). Mol Cell Biochem. 2006;282:15767.

2. Atamer Y, Koçyigit Y, Yokus B, Atamer A, Erden AC. Lipid peroxidation, antioxidant defense, status 
of trace metals and leptin levels in preeclampsia. Eur J Obstet Gynecol Reprod Biol. 2005;119:60-6.

3. Wei SQ, Audibert F, Hidiroglou N, Sarafin K, Julien $\mathrm{P}, \mathrm{Wu} \mathrm{Y}$, et al. Longitudinal vitamin $\mathrm{D}$ status in pregnancy and the risk of pre-eclampsia. BJOG. 2012 Jun;119(7):832-9.

4. Holick MF. Vitamin D deficiency. N Engl J Med. 2007 Jul 19;357(3):266-81.

5. Heaney RP. Functional indices of vitamin D status and ramifications of vitamin D deficiency. Am J Clin Nutr. 2004; 80(6):1706-9.

6. Malabanan A, Veronikis IE, Holick MF. Redefining vitamin insufficiency. Lancet.1998; 351:805-6.

7. Heaney RP, Dowell MS, Hale CA, Bendich A. Calcium absorption varies within the reference range for serum 25-hydroxy vitamin D. J Am Coll Nutr. 2003;22:142-6.

8. Hansen KE, Jones AN, Lindstrom MJ, Davis LA, Engelke JA, Shafer MM. Vitamin D insufficiency: disease or no disease. J Bone Miner Res. 2008;23:1052-60.

9. Bischoff-Ferrari HA, Can U, Staehelin HB, Platz A, Henschkowski J, Michel B, et al. Severe vitamin D deficiency in Swiss hip fracture patients. Bone. 2008;42:597-602.

10. Ross AC, Taylor CL, Yaktine AL, Del Valle. Dietary reference intakes for calcium and vitamin $D$. Washington (DC): National Academic Press (US);2011.

11. Hollis BW, Wagner CL. Vitamin D requirements during lactation: high-dose maternal supplementation as therapy to prevent hypovitaminosis D for both the mother and the nursing infant. Am J Clin Nutr. 2004;80:1752-8.

12. Lee JM, Smth JR, Philipp BL, Chen TC, Mathieu J, Holick MF. Vitamin D deficiency in a healthy group of mothers and newborn infants. Clin Pediatr (Phila). 2007;46:42-4.

13. Bodnar L, Simhan HN, Powers RW, Frank MP, Cooperstein E, Roberts JM. High prevalence of vitamin D insufficiency in black and white pregnant women residing in the Northern United States and their neonates. J Nutr. 2007 Feb;137(2):447-52.
14. Sadin B, Pourghassem Gargari B, Pourteymour Fard Tabrizi F. Vitamin D status in preeclamptic and nonpreeclamptic pregnant women: a case-control study in the North West of Iran. Health Promot Perspect. 2015 Oct 25;5(3):183-90.

15. Tabesh M, Salehi-Abargouei A, Tabesh M, Esmaillzadeh A. Maternal vitamin D status and risk of pre-eclampsia: a systematic review and metaanalysis. The J Clinical Endocrinol Metabol. 2013, August;98(8):3165-73.

16. Aghajafari F, Nagulesapillai, Ronksley P, Tough S, O'Beirne M, Rabi D. Systematic review and metaanalysis of observational studies. BMJ. 2013;346:f1169.

17. Umar N, Tauseef A, Shahzad F, Sabir S, Kanwal S, Akmal A et al. Serum 25- Hydroxy Vitamin D level in preeclamptic and normotensive pregnancies. J Coll Physic Surg Pak. 2016;26(8):673-6.

18. Gupta T, Wahi S, Gupta N, Arora S, Gupta S, Bhatia P. Correlation of Vitamin D levels in term normotensive and pre-eclamptic patients in labor. J Obstet Gynaecol India. 2016 Jun;66(3):154-9.

19. Mehmood S, Karim SA. Vitamin D deficiency during pregnancy and its relationship with preeclampsia, eclampsia and gestational hypertension. Austin J Nutr Metab. 2016;3(2):1040.

20. Robinson CJ, Wagner CL, Hollis BW, Baatz JE, Johnson DD. Maternal vitamin D and fetal growth in early-onset severe preeclampsia. Am J Obstet Gynecol. 2011;204(6):556.

21. Goel P, Garg G, Kaur J, Mehra R, Tandon R, Huria A. Association of vitamin $\mathrm{D}$ deficiency during pregnancy with preeclampsia and eclampsia. Int J Reprod Contracept Obstet Gynecol. 2016 Sept;5(9):3046-50.

Cite this article as: Kaur G, Pahwa S, Preet I. Prevalence of vitamin D deficiency in patients of pregnancy induced hypertension. Int J Reprod Contracept Obstet Gynecol 2018;7:3358-61. 